\title{
The Comparison of Self-Efficacy Belief Levels on Anatomy Education between the Undergraduate Students from Physical Therapy and Rehabilitation Department and the Associate Students from Vocational School of Health Services in Western Black Sea Region
}

\author{
Derya Acar ${ }^{1}$, Tuncay Colak ${ }^{2}$, Serap Colak ${ }^{3}$, Tugba Gungor ${ }^{1}$, Deniz M Yener ${ }^{2}$, Elif Aksu ${ }^{2}$, Dilsat Guzelordu ${ }^{2}$, \\ Ismail Sivri ${ }^{2}$, Enis Colak ${ }^{3} \&$ Abdullah Ors $^{2}$ \\ ${ }^{1}$ Vocational School of Health Services, Karabuk University, Karabuk, Turkey \\ ${ }^{2}$ Anatomy Department, Kocaeli University, Faculty of Medicine, Kocaeli, Turkey \\ ${ }^{3}$ Faculty of Sport Science, Kocaeli University, Kocaeli, Turkey \\ Correspondence: Serap Colak, Department of Sports Management and Sports Anatomy, Faculty of Sport Science, \\ Kocaeli University, Kocaeli, Turkey. E-mail: srpclk@gmail.com
}

Received: February 17, 2017

Accepted: March 24, 2017 Online Published: April 12, 2017

doi:10.5539/jel.v6n3p151

URL: http://doi.org/10.5539/jel.v6n3p151

\begin{abstract}
Physical Therapy and Rehabilitation (PTR) undergraduate degree departments and Vocational School of Health Services (VSHS) associate degree departments train healthcare professionals, which is important for both continuance of human health and treatment of various illnesses. Anatomic structures underlie the illnesses that these departments treat and care.

Therefore, the graduates of these departments should have favorable knowledge of anatomy. The aim of this study is to evaluate and compare the self-efficacy belief levels about anatomy education of PTR students as undergraduate and VSHS students as associate degree.

94 students from PTR department (age: 21.94 \pm 1.19 ) and 100 students from VSHS (age: $20.16 \pm 1.58$ ) have participated in the study. Data collection questionnaire (gender, age, geographical region where he/she came from, residential place) and Anatomy Self-Efficacy Belief scale (ASEB) have been implemented on the participants.

As a consequence, when the Anatomy Self-Efficacy Belief levels of undergraduate and associate degree students are compared, no significant difference has been found in total $(p>0,05)$. However, when the answers given to the questions in self-efficacy belief level test are compared separately, a significant difference has been found in 4 questions $(p<0,05)$. The reason for this is that the students of PTR department have more hours of anatomy lesson per week compared to the students of VSHS.

As ASEB gets better, profession is done better in view of anatomy. This will help the graduates of both departments do their profession better and be more helpful to their patients.
\end{abstract}

Keywords: anatomy, education, physical therapy

\section{Introduction}

Anatomy is one of the most basic lessons of the departments that give education in the field of health sciences. In this context, the main objective of the departments at universities that give education in field of Health Sciences is to keep everybody healthy and make it better (Edinburgh Declaration, 1988; Buyukmumcu et al., 2013). In order to be successful in Physical Therapy and Rehabilitation (PTR), human anatomy should be conceived well. While the number of anatomy lessons in Karabuk University School of Health PTR Department is 8 hours per week, this number is 3 hours per week at Karabuk University Vocational School of Health Services (VSHS) Associate Degree Departments. The aim of the study is to evaluate and compare the effect of the difference in the number of lesson hours on the students' Anatomy education Self-Efficacy Beliefs (ASEB). 
Self-efficacy has been first defined by Bandura (1977) in educational methodology. This researcher defines the term self-efficacy as the ability to overcome the problems that the person encounters about his life or work. Afterwards, self-efficacy concept has been improved by many researchers and used in various professional groups and different educational fields (Tasdemir et al., 2015; Colak, 2013; Akkoyunlu \& Orhan, 2003). The fact that how well an individual performs the actions necessary for solving the problems that he encountered in any stage of the education shows the level of individual's self-efficacy on that subject. This shows that the level of individual's self-efficacy is the ability to perform an action and to success in it (Tasdemir et al., 2015; Colak, 2013). There are studies that discuss which educational models should be implemented in the health departments of universities and which effective methods should be used in order to reach the target level in these educational models (Colak et al., 2014; Buyukmumcu et al., 2013; Arli, 2013; Akpinar et al., 2004; Ari et al., 2003; Nkanginieme \& Eke, 2001). The purpose of getting the Self-Efficacy Belief Levels of students for anatomy education is to pay attention to the thoughts of students on this subject and to make the students evaluate the education.

While undergraduate students of PTR department should know very well about general anatomy and musculoskeletal anatomy after graduation, the graduate students from Vocational School of Health Services (VSHS) should know very well about general anatomy. This will help the graduates of both departments do their profession better and help their patients better.

\section{Material-Method}

\subsection{Subjects}

The study participants consisted of 94 students from PTR department (age: $21.94 \pm 1.19$ ) and 100 students from VSHS (age: $20.16 \pm 1.58$ ).

\subsection{Data Collection}

The data were obtained with using a questionnaire developed by Akkoyunlu and Orhan (2003) and analysed according to ASEB scale. The answers of the questions stated below can be one of the "Fully Agree", "Agree", "Indifferent" "Disagree", and "Fully Disagree". Respectively, the score for the answers are 5, 4, 3, 2 and 1. Addition of score of the 15 answers gives the Anatomy Self-Efficacy Belief Scale (ASEB) of the participant.

(1): It makes me happy to learn new things about anatomy. 2): I work hard to overcome the problems by myself while learning anatomy. 3): I think studying anatomy is easy. 4): I have difficulty in learning new things about anatomy. 5): It distresses me to be obliged to use anatomy knowledge while doing my job. 6): I usually have problems while using my anatomy knowledge. 7): For me, anatomy is an extremely complicated lesson. 8): I don't use my anatomy knowledge unless I need. 9): I believe that I will be successful in my profession by learning anatomy. 10): I can say that I have a favorable knowledge of anatomy. 11): I feel panic when I have problem while learning anatomy. 12): I believe that everybody who is eager can learn anatomy. 13): I believe that I have enough anatomy knowledge to fulfill my needs. 14): I necessarily ask for help when I have a problem studying anatomy lesson. 15): I'm afraid of making mistakes that cannot be corrected owing to lack of anatomy knowledge.)

\subsection{Data Collection Questionnaire}

The questionnaire was used to collect data about students' ages, genders, region of origin and places of residence.

\subsection{The Anatomy Self-Efficacy Belief Scale}

Self-Efficacy Belief scale questions were adapted to Anatomy lesson. It was named as Anatomy Self-Efficacy Belief Scale that was composed of the answers of 15 item questions stated above (Colak, 2013; Akkoyunlu \& Orhan, 2003).

\subsection{Statistical Analysis}

The data were analyzed using the SPSS software package (SPSS for Windows v. 18.0, SPSS, Chicago, IL, USA). The means and standard deviations of each of the items measured were calculated. The differences between the means for each group were determined using a nonparametric test for independent samples (the Mann-Whitney $\mathrm{U}$ test). A $\mathrm{p}$ value of 0.05 was considered statistically significant. 


\section{Results}

Among the 94 participants (age: 21.94 \pm 1.19$)$ from PTR department in this study, 12 students $(12.8 \%)$ are from Mediterranean Region, 16 students (17\%) are from Black Sea Region, 14 students (14.8\%) are from Aegean Region, 22 students (23.4\%) are from Marmara Region, 7 students (7.4\%) are from East Anatolia Region, 10 students (10.6\%) are from Southeast Anatolia Region (Table 1).

In addition, among the 100 participant students $(20.16 \pm 1.58)$ at VSHS in the study, 11 students (11\%) are from Mediterranean Region, 50 students (50\%) are from Black Sea Region, 6 students $(6 \%)$ are from Aegean Region, 9 students (9\%) are from Marmara Region, 4 students (4\%) are from East Anatolia Region, 2 students (2\%) are from Southeast Anatolia Region and 18 students (18\%) are from Central Anatolia Region (Table 2).

The students' answers are examined and compared in view of ASEB scale. When the answers given to the $2^{\text {nd }}$, $8^{\text {th }}, 9^{\text {th }}$ and $14^{\text {th }}$ questions are compared, a significant difference has been found statistically $(p<0,05)$ (Table 3 ).

Table 1. Distribution of PTR students according to the regions they come from

\begin{tabular}{lcc}
\hline Geographical Regions & Number & Percentage \\
\hline Mediterranean & 12 & 12.8 \\
Black Sea & 16 & 17 \\
Aegean & 14 & 14.9 \\
Marmara & 22 & 23.4 \\
East Anatolia & 7 & 7.4 \\
South East Anatolia & 10 & 10.6 \\
Central Anatolia & 13 & 13.8 \\
\hline
\end{tabular}

Table 2. Distribution of VSHS students according to the regions they come from

\begin{tabular}{lcc}
\hline Geographical Regions & Number & Percentage \\
\hline Mediterranean & 11 & 11 \\
Black Sea & 50 & 50 \\
Aegean & 6 & 6 \\
Marmara & 9 & 9 \\
East Anatolia & 4 & 4 \\
South East Anatolia & 2 & 2 \\
Central Anatolia & 18 & 18 \\
\hline
\end{tabular}

When the geographical regions where the students from both departments come from are observed, as PTR students enter their departments after being successful in the exam that OSYM (Student Selection and Placement Central in Turkey) conducts, most of the students come from Marmara Region and there are also students from all other geographical regions. As VSHS students can enter their departments through vertical transfer, it has been seen that most of the students come from Black Sea Region where Karabuk University is located. 
Table 3. Comparison of PTR and VSHS students according to the answers to the questions at ASEB scale

\begin{tabular}{|c|c|c|c|}
\hline Questions & $\begin{array}{l}\text { ASEB Average of } \\
\text { PTR Students }\end{array}$ & $\begin{array}{l}\text { ASEB Average of } \\
\text { VSHS Students }\end{array}$ & $P$ value \\
\hline 1 & $4.22 \pm 0.963$ & $4.08 \pm 0.884$ & 0.104 \\
\hline 2 & $3.82 \pm 0.789$ & $3.52 \pm 0.882$ & 0.001 \\
\hline 3 & $2.78 \pm 1.059$ & $2.75 \pm 0.989$ & 0.938 \\
\hline 4 & $3.02 \pm 1.005$ & $2.91 \pm 0.954$ & 0.329 \\
\hline 5 & $2.34 \pm 1.132$ & $2.36 \pm 0.927$ & 0.495 \\
\hline 6 & $2.70 \pm 0.971$ & $2.64 \pm 0.811$ & 0.581 \\
\hline 7 & $2.64 \pm 0.971$ & $2.92 \pm 0.950$ & 0.065 \\
\hline 8 & $2.53 \pm 0.980$ & $3.05 \pm 1.123$ & 0.001 \\
\hline 9 & $4.47 \pm 0.772$ & $3.96 \pm 0.994$ & 0.000 \\
\hline 10 & $2.91 \pm 0.838$ & $2.84 \pm 0.849$ & 0.286 \\
\hline 11 & $2.67 \pm 1.111$ & $2.81 \pm 1.098$ & 0.400 \\
\hline 12 & $3.98 \pm 0.939$ & $4.12 \pm 1.037$ & 0.146 \\
\hline 13 & $3.31 \pm 0.855$ & $3.44 \pm 0.857$ & 0.408 \\
\hline 14 & $2.96 \pm 0.815$ & $3.41 \pm 1.120$ & 0.001 \\
\hline 15 & $3.48 \pm 1.024$ & $3.56 \pm 1.225$ & 0.360 \\
\hline
\end{tabular}

When the answers that the students from PTR department and VSHS have given to the questions in the ASEB scale are compared, there is not a significant difference statistically in view of the answers to the $1^{\text {st }}, 3^{\text {rd }}, 4^{\text {th }}, 5^{\text {th }}$, $6^{\text {th }}, 7^{\text {th }}, 10^{\text {th }}, 11^{\text {th }}, 12^{\text {th }}, 13^{\text {th }}, 15^{\text {th }}$ questions $(p>0,05)$. When the answers that the students from PTR department and VSHS have given to the questions in the ASEB scale are compared, there is a significant difference statistically in view of the answers to the $2^{\text {nd }}, 8^{\text {th }}, 9^{\text {th }}$ and $14^{\text {th }}$ questions $(\mathrm{p}<0,05)$.

\section{Discussion}

The information on the data questionnaire that has been adapted to the PTR and VSHS students (gender, age, geographical region where he/she came from, residential place) has been evaluated. These parameters have been compared with ASEB levels and correlated within themselves. As a result, when the Anatomy Self-Efficacy Belief levels of undergraduate and associate degree students are compared, no significant difference has been found in total $(\mathrm{p}>0,05)$. However, when the answers given to the questions in self-efficacy belief level test are compared separately, a significant difference has been found in 4 questions $(p<0,05)$. The reason is that the anatomy lesson hours per week of the PTR students are more than that of VSHS students.

There are studies which show the self-efficacy belief scale can be used in the field of education (Colak, 2013; Zimmerman, 2000). There are also studies of faculty of medicine being in the first place and other departments that give education in the field of health which use self-efficacy in educational methodology (Tasdemir et al., 2015; Lok et al., 2009). Starting from this point of view, it is desired to measure and compare Anatomy lesson Self-Efficacy Belief levels of PTR and VSHS students. By this means, the data have been obtained in order to give more productive theoretical and practical anatomy education in these departments.

There are also studies about expressing the relationship between self-efficacy belief and studying methods. Tembo and Ngwira (2016) found significant difference between ASEB and studying anatomy lesson styles. As for this study, the students who have higher ASEB scale study Anatomy less than the others. The sample population consisted of the 2014 undergraduate Bachelor of Medicine Bachelor of Surgery (MBBS) year one students from University of Malawi, College of Medicine Self-efficacy beliefs on learning strategies (UMCOM), in their second semester of Anatomy studies just before their end of semester 2 examinations.

There are some studies about the impact of students' residences on ASEB. Tasdemir et al. (2016) found that the nursing students' residences (dormitory or home) have an impact on the ASEB scale. They found that the students who reside in dormitory have a higher ASEB. However, in this study it isn't found any difference in view of residences. 
When the parameters in the data questionnaire are evaluated in view of the regions they come from, the residential places and age, significance has been found in some studies (Tasdemir et al., 2015). However, no significance has been found in the study. When their answers to the questions in the ASEB scale are compared, a significant difference has been found in the answers to the $2^{\text {nd }}, 8^{\text {th }}, 9^{\text {th }}$ and $14^{\text {th }}$ questions. These questions are: (2) (I work hard to overcome the problems by myself while learning anatomy), (8) (I don't use my anatomy knowledge unless I need), (9) (I believe that I will be successful in my profession by learning anatomy), (14) (I necessarily ask for help when I have a problem studying anatomy lesson).

These questions show qualitatively that the students from PTR department see themselves more sufficient in view of anatomy knowledge and trust in themselves more with regard to both professional and anatomy knowledge.

It is seen in the study that graduate students should have a sufficient knowledge of anatomy. The aim of this study is to search and compare the self-efficacy belief levels about anatomy education of PTR students as undergraduate and VSHS students as associate degree.

The self-efficacy belief levels about anatomy lesson of PTR and VSHS students are desired to determine in order to examine their anatomy knowledge. Correspondingly, it is valuable to learn about how the students' self-efficacy belief levels about both anatomy and the other lessons will effect their professional life. Because the fact that having sufficient anatomy knowledge will help both PTR and VSHS students do their profession better and help their patients better.

There are a few limitations for this study. Obtaining the data from the questionnaire may give false results. The participants may give the answers without reading the questions or not answer to all of the questions. The other problem is that all of the participants are from Karabuk University. Therefore, the group may not represent all of the students who take Anatomy lesson.

It is recommended that the self-efficacy belief scale can be applied to other branches. If the studies like this increase, the students will be analyzed better. Therefore, if any problem is determined, some educational changes will be performed. Finally, ASEB can be evaluated as a scale that represent the Anatomy knowledge. It is hoped that if the practice hours increase in all of the lessons like Anatomy, self-efficacy belief scale will increase automatically. The students who have higher self-efficacy will be more successful in their prospective business lives.

\section{References}

Akkoyunlu, B., \& Orhan, F. (2003). Bilgisayar ve Ogretim Teknolojileri Egitimi (BOTE) Bolumu Ogrencilerinin Bilgisayar Kullanma Oz Yeterlik Inanci ile Demografik Ozellikleri Arasindaki Iliski. Turk. Online J. Educ. Technol, 2(3), 86-93.

Akpinar, E. et al. (2004). Cukurova Universitesi Tip fakultesi ogrencileri ve ogretim elemanlarinin tip bilisimi egitimi konusundaki gorus ve onerileri. Ulusal Tip Egitimi Kongresi Sanliurfa, Kongre Kitabi.

Ari, I., Irgil, E., Kafa, I. M., \& Sendemir, E. (2003). A Questionnaire Study: Anatomy Education And Student's Views. Uludag Medical Journal, 29(2), 8-15.

Arli, E. (2013). Review of the Effects of Housing Place on Individual and Social Development and Academic Success of University Students by Focus Group Discussion. Journal of Higher Education and Science, 3(2), 173-178. https://doi.org/10.5961/jhes.2013.073

Bandura, A. (1977). Selfefficacy: Toward a unifying theory of behaviour change. Psychol. Rev., 84, 191-215. https://doi.org/10.1037/0033-295X.84.2.191

Buyukmumcu, M., Aydin A. D., Akin, D., \& Yilmaz, M. T. (2013). Medical Students' Views about Practical Lessons' Slides Which Used Education of Practical Anatomy. Selcuk Tip Dergisi, 29(2), 71-74.

Colak, S. (2013). The Relationship Among Computer Self-efficacy Scores, Demographic Charecteristics and Grades in Computer Courses of Students at the School of Physical Education and Sports. Educational Research And Reviews, 8(8), 374-377.

Colak, T., Bamac, B., Ozbek, A., Tasdemir, R., Aksu, E., \& Yener, M. D. (2014). Opinion of Students Who have Taken Anatomy Lesson at University Regarding the Anatomy Laboratory Education. In INTE 2014, International Conference on New Horizons in Education (pp. 25-27). Paris, France.

Edinburgh Decleration of WFME. (1988, August 7-12). World Conference on Medical Education-Report. Edinburgh, Blackwood Pillans \& Wilson, Edinburgh. 
Lok, S., Tasgin, O., Lok, N., \& Yildiz, M. (2009). Comparing the Karamanoglu Mehmet University Students' Self-Ability for Anatomy Lesson in Diffrent Branches. Selcuk Universitesi Sosyal Bilimler Enstitusu Dergisi, 21, 339-345.

Nkanginieme, K. E., \& Eke, N. (2001). Learning and evaluation in medical education. Niger Postgrad Med J., 8, 46-51.

Tasdemir, R., Colak, S., Sivri, I., Yener, M. D., Guzelordu, D., Colak, T., ... Rahova, G. (2015). The Comparison of Self-Efficacy Beliefs of Anatomy betweent the First and the Second Class Students in Medical School. TOJET: The Turkish Online Journal of Educational Technology, 2, 570-574.

Tasdemir, R., Sivri, I., Güzelordu, D., Yener, M. D., Aksu, E., Colak, S., ... Colak, T. (2016). Determination of nursing students' self-efficacy belief levels in anatomy lectures SHS Web Conf.

Tembo, L. H., \& Ngwira, F. N. (2016). The impact of self-efficacy beliefs on learning strategies: Towards learning Human Anatomy at College of Medicine. $J$ Contemp Med Edu, 4(2). https://doi.org/10.5455/jcme.20160603033340

Zimmerman, B. J. (2000). Self Efficacy: An Essential Motive to Learn. Contemporary Educational Psychology, 25, 82-91. https://doi.org/10.1006/ceps.1999.1016

\section{Note}

Note 1. Part of this study was presented as a poster in the International Congresses on Education ERPA 2016, Sarajevo/Bosnia and Herzegovina, 2-5 June 2016.

\section{Copyrights}

Copyright for this article is retained by the author(s), with first publication rights granted to the journal.

This is an open-access article distributed under the terms and conditions of the Creative Commons Attribution license (http://creativecommons.org/licenses/by/4.0/). 